\title{
South Korean's Auto Industry: The Influence Of Design, Fuel Efficiency, Price, Quality, And Technology On US Consumers' Purchasing Decision
}

\author{
Abdullah Alshboul, DBA \\ Yiming Wang, DBA \\ Argosy University/Chicago, USA
}

doi: 10.19044/esj.2016.v12n22p38 URL:http://dx.doi.org/10.19044/esj.2016.v12n22p38

\begin{abstract}
The purpose of this quantitative research was to identify whether there were correlations between U.S. automobile consumers' perceived value and South Korean automobiles' price, quality, fuel efficiency, design, and technologies. The sample size of the current study was 538. A questionnaire was used to collect data from automobile consumers in 50 states and in the District of Columbia. The results show that consumers' perceived value were positively related to South Korean automobiles' price, quality, fuel efficiency, design, and technologies. The result of a multiple regression analysis shows that South Korean automobiles' quality, fuel efficiency, design, and technologies were significant predictors of consumers' perceived value. On the other hand, price was only a marginally significant predictor of consumers' perceived value. In the second multiple regression analysis which considers the participants' gender, age, education level, and income level, results indicated that none of the four variables had any effect on consumers' perceived value. Implications for South Korean automobiles' pricing, quality control, and manufacturing strategy are discussed. Directions for future research are also proposed.
\end{abstract}

Keywords: South Korean automobiles, consumers' perceived value, price, quality

\section{Introduction}

Both Hyundai and Kia have seen considerable sales increases in the United States. According to Hyundai's own reports, in 1986, the company sold 168,882 cars in the U.S. market (Hyundai, n.d.). In 2014, Hyundai sold a total of 725,718 cars to U.S. consumers, which was a $330 \%$ increase (Harper, 2015). In 1994, Kia only sold 692 cars to U.S. consumers (Henry, 2013). However, in 2014, Kia sold a total of 246,769 cars in the United 
States according to its financial reports. Kia reached a 356\% increase during its 20 years of development in the United States (Kia Media, 2014). Bullas (2012) explained that product quality, including reliability, working life, economic cost of ownership, and customer support are the core aspects of judging a product's value. Therefore, product quality has a strong correlation with the product's value (Bullas, 2012). Goodson (2012) pointed out that product quality is one of the most significant considerations when consumers are evaluating a brand. Good product quality can increase the brand's value for consumers, while bad product quality can decrease a brand's image and perceived consumer value (Apelbaum, 1999). In addition, Watson (2015) found that a negative post related to product quality can have a stronger impact on a brand's value than a positive post. Therefore, Watson suggested that businesses should strive for stable and increasing quality performance in their product lines in order to shape an approbatory reliable brand in perceived consumer value.

According to Schweinsberg (2014), the popularity of South Korean automobile brands, such as Kia, had not changed much in the past 20 years. In addition, relatively few studies have been conducted with South Korean automobile manufacturers and products. However, the literature gap encouraged the current researchers of this study to focus attention on researching South Korean automobile brands to discover their current situations and future opportunities. A similar fact was reflected in two different articles by Ewing (2014) and Cato (2014), in that they reported that some consumers did not realize that South Korean automobile manufacturers had been working to increase the quality and value of their products to a whole new level. Therefore, it was necessary to establish a quantitative analysis of the perceptions held by U.S. consumers of South Korean automobile brands to discover whether the changes made to Hyundai's and Kia's products affected perceived consumer value. The main focus of this research is to answer the following question: What is the impact of South Korean automobiles' price, quality, fuel efficiency, and benefits on U.S. consumers' perceived value? Consequently, the following hypotheses were developed:

$\mathrm{H} 1_{\mathrm{a}}$ : South Korean automobiles' price changes will have a significant impact on U.S. consumers' perceived value.

$\mathrm{H} 1_{0}$ : South Korean automobiles' price changes will not have a significant impact on U.S. consumers' perceived value.

$\mathrm{H} 2$ a : South Korean automobiles' quality changes will have a significant impact on U.S. consumers' perceived value.

$\mathrm{H}_{2}$ : South Korean automobiles' quality changes will not have a significant impact on U.S. consumers' perceived value. 
H3a: South Korean automobiles' fuel efficiency will have a significant impact on U.S. consumers' perceived value.

$\mathrm{H}_{0}$ : South Korean automobiles' fuel efficiency will not have a significant impact on U.S. consumers' perceived value.

$\mathrm{H} 4_{\mathrm{a}}$ : South Korean automobiles' design will have a significant impact on U.S. consumers' perceived value.

$\mathrm{H} 4_{0}$ : South Korean automobiles' design will not have a significant impact on U.S. consumers' perceived value.

H5a: South Korean automobiles' technologies will have a significant impact on U.S. consumers' perceived value.

H50: South Korean automobiles' technologies will not have a significant impact on U.S. consumers' perceived value.

Furthermore, the research question and hypotheses indicated several key elements in this study.

\section{Literature review}

Garvin (1984) showed that product quality has a strong effect on consumers' perceived value, while Wasserman (2010) found price to be another factor with a strong ability to affect consumers' perceived value. Along with the fast development of the business world, Sharp (2012) found that more consumers compare different brands and make purchasing decisions by considering not only the product quality, but also the benefits of using the product. According to his findings, product benefit makes up a more significant part of consumers' perceived value (Sharp, 2012). Numerous previous and present studies indicated that there are strong correlations between consumers' perceived value and a product's price, quality, and benefits in more general terms.

\section{Consumer Perceived Value}

According to Yang (2006), consumer perceived value reflects consumers' satisfaction with a product. A key component of perceived value is the benefit perceived by consumers (Yang, 2006). Consumer satisfaction can be increased by obtaining more benefits during the time of using a product. Yang also pointed out that one consumer's perceived value can strongly affect other people's purchase decisions. Therefore, it is important for companies to determine how to increase the value their consumers can perceive from the product so they can engage in positive word of mouth marketing with other consumers.

Schniederjans et al. (2011) provided a good example of how to investigate American consumers' perceived value with their study in which they targeted products made in China. Schniederjans et al. randomly surveyed 1,000 American people and received 856 responses. A total of 713 
qualified participants out of the 856 responses were obtained from this survey. Thus, these 713 participants were chosen from 50 states (Schniederjans et al., 2011).

Schniederjans et al. (2011) found that American people believe Chinese products were of lower quality compared to products made in other countries. Design problems, missing parts, and a short product life were the three major problems that appeared in the data (Schniederjans et al., 2011). Second, American people overwhelmingly perceived that the majority of non-Chinese products had greater net values than Chinese products (Schniederjans et al., 2011). Last, Schniederjans et al. discovered that there was no obvious trend to suggest that American customers would stop buying Chinese products. Cheaper prices were the main reason for American people choosing to purchase Chinese products.

Schniederjans et al. (2011) developed an effective model of how to investigate Americans' perceptions of certain kind of products. Schniederjans et al. focused on Chinese products, while the focus of the current study is on South Korean automobile brands. Although there was a literature gap between the two studies, the method and measurements used in Schniederjans et al.'s study were helpful in the process of conducting this research with South Korean automobiles.

The automobile market is well developed in the United States (Coffey \& Layden, 1996). As there are many manufacturers competing in the market, it can be difficult for customers to choose the best products to fit their demands. In 2014, a total of 16.5 million new cars were sold to American customers (Kessler, 2015). Hence, organizations that provide comparison results between different brands play an important role in the market.

TrueCar is a data-driven website. Consumers can access this site to gain information about Market-based pricing data on cars, and to connect with certified dealers. Customers can easily learn about the performance, price, and safety test results of different brands and models in a single site. In addition, TrueCar publishes annual evaluation reports of automobile brands according to information collected from the industry and market. TrueCar rates each aspect and then summarizes and grades each brand. TrueCar (2013) evaluation results uncover the practical value of cars rather than relying on company advertisements. However, TrueCar only concentrated on superficial marketing data and did not go deeper to analyze consumers' perceived value of each brand. As a result, the current study was designed to fill the literature gap to investigate U.S. consumers' perceived value of Hyundai and Kia in order to provide detailed findings and suggestions for increasing the business performance of these companies. 
Cato (2014) wrote an analysis paper about Canadians’ perceived value surrounding Hyundai and Kia and found that Hyundai and Kia had been improving their product quality a lot during the last decade. However, he also found that the improvements in these two brands were not recognized by Canadians. In other words, most Canadian customers still thought that South Korean automobiles were of low quality.

Cato (2014) conducted an experiment and invited Canadian people to test drive a car that had its logo covered. Most participants praised the quality, such as a quiet engine, easy control, and smooth brakes. When the logo of the test car was discovered, most participants were amazed that it was a Hyundai. In addition, Cato interviewed these participants about whether they would buy a Hyundai in the future. Answers revealed the participants may have changed their perceptions of Hyundai. Thus, they needed more comparison with other brands to make a purchase decision.

Cato (2014) concluded that most Canadian consumers did not pay much attention to the improvements made by Hyundai and Kia, and still held onto their old perceptions of these two brands. Second, most current Canadian consumers kept their loyalty to traditional brands such as Ford, Toyota, and BMW. Their purchase decisions would be hard to change even though they realized the improvements in South Korean automobiles. Third, Cato pointed out that Hyundai and Kia still had some disadvantages that dragged their products' values down in consumers' minds. For example, Cato found that Kia had some new models with refreshed designs, but still installed old engines and transmission systems. Kia's management team did not show enough spirit of updating their products' value and competitiveness, but chose to manufacture conservatively.

\section{Product Price}

Pricing is another significant factor for business development (Wasserman, 2010). An appropriate price can enhance the volume of sales, while a wrong pricing strategy can generate problems that have the potential to damage the business (Wasserman, 2010). Setting a good price for a product is an important but difficult job (Wasserman, 2010). Therefore, there is no single pricing strategy or mode that will fit every product. In fact, companies need to make a specific pricing plan for every single product by considering several key factors, such as consumers, competitors, quality, and costs (Wasserman, 2010).

Business leaders often have a great deal of flexibility in pricing (Wasserman, 2010). According to Wasserman (2010), before determining a pricing strategy, companies must understand that price is a function of the ability to sell. Price helps companies generate enough revenue to cover the production costs and support future development. Wasserman pointed out 
that bad pricing usually falls into two categories: under-pricing or overpricing. Wasserman noted that many companies try to use lower prices to drive up sales volume, especially in an economic downturn. However, a low price can cause the consumer to simply perceive the product to be cheap with low quality. According to Wasserman's research, consumers are more willing to spend money on a worthy product, but will not spend on a product with less value. Therefore, under-pricing can damage a company's reputation and generate barriers to future development. Over-pricing, on the other hand, can scare customers out the door and push them to competitors (Wasserman, 2010). Wasserman suggested that business leaders must understand consumers' perspectives of the product and what price they are willing to pay. This is the beginning of a strategic plan.

\section{Product Quality}

Product quality is another factor that plays significant role in market competition (Garvin, 1984). According to Garvin (1984), marketers and manufacturers view product quality from different vantage points. Marketers evaluate product quality based on customer satisfaction and buying behaviors. On the other hand, manufacturers are focused on quality control in the production process and innovation in engineering practices. Therefore, these two groups have totally different analytical frameworks for product quality investigations.

At a basic level, marketers and manufacturers use two different approaches to define product quality. Garvin (1984) pointed out that the user-based approach is the common method of defining product quality in the marketing field. The user-based definition can be found in the eyes of the beholder (Garvin, 1984). Product quality is usually measured by how well the product satisfies customers' demands (Garvin, 1984). The userbased approach fits the focus of marketing departments (Garvin, 1984). However, it is difficult to collect satisfaction levels from every single customer. A consensus in the marketing field is that high-quality products should meet the demands of a majority of consumers (Garvin, 1984).

The manufacturing-based approach is adapted by most operational management (Garvin, 1984). They evaluate product quality from the side of supply. Basically, the manufacturing-based approach defines product quality by whether the product meets the requirements and standards of designs and specifications (Garvin, 1984). High-quality products should meet all specifications without any defect on each component of the product (Garvin, 1984). It requires a well thought out design as well as careful quality control at every phase of the manufacturing process. It is not easy to ensure that every product will be of high quality. Manufacturers need to expend a lot of 
cost on tests, remodel, repair, and rework in order to maintain a high level of product quality (Garvin, 1984).

Garvin (1984) pointed out that the different approaches generate conflicts between the demand and supply sides. For example, according to the manufacturing-based approach, a Mercedes automobile and a Toyota automobile both have high quality if they meet the manufacturer's specifications. However, in consumers' eyes, a Mercedes may have better quality than a Toyota as it can better satisfy their demand of owning a luxury brand.

This kind of conflict can result in more serious problems that can damage the business (Garvin, 1984). Therefore, Garvin (1984) suggested management break the bias between the marketing and manufacturing departments. Enhancing the communication between these two departments can help each department understand the other's views and work together to improve the business. First, Garvin suggested the marketing department needs to do research to collect as much information about consumer demands as possible. Second, people in the design department can use the information related to market demand to build identifiable product attributes and use them as the specifications in the manufacturing process. Last but not the least, workers in the manufacturing lines need to take the highest level of quality control when making every product. They have the responsibility of ensuring that the product matches the requirements and specifications. Therefore, the combination of these three steps will enhance the product's quality. Missing any step can cause the business to fail (Garvin, 1984).

In addition, Garvin (1984) pointed out that both the user-based and manufacturing-based approaches have the problem of ignoring the basic elements of product quality. He mentioned several aspects as a framework for identifying product quality. Feature, as the first aspect, describes the basic functions of the product, just like speakers in a music player or the spin function on a washing machine (Garvin, 1984). These functions are the features of the product designed to satisfy the buyers' basic needs. Therefore, features (i.e., function) are important elements of designing a product because they are in the first line of customers' evaluations (Garvin, 1984).

The second element is product reliability (Garvin, 1984). Reliability reflects the probability of a product's malfunction or breakdown in a specified period of time. Garvin provided several measurements for evaluating product reliability, including the mean time to first failure, the mean time between failures, and the failure rate per unit time. According to Garvin (1984), reliability becomes more and more important for customers to evaluate a product's quality because it directly relates to the cost of repairing or rebuying. Therefore, manufacturers must pay much attention to 
these elements during production in order to ensure the product is of high quality (Garvin, 1984).

Moreover, Garvin (1984) stated that features and reliability as the internal elements of the products are as significant for a product's quality as the external elements such as look, feel, sound, taste, or smell. According to Garvin, these elements have a significant impact on customers' judgments of a product's quality. Therefore, a well thought out design of these elements can help to capture customers' attention and enhance perceived quality (Garvin, 1984).

Garvin (1984) provided a profound analysis of product quality and dissected how to use an appropriate approach to identify a product's quality that will fit both the consumer's and manufacturer's view. In addition, he listed several elements that are important for identifying a product's quality. Therefore, Garvin's study was close to the current study topic, which was consumers' perceptions of the quality of South Korean automobiles. However, Garvin's research involved a general view of all kinds of businesses. Although he provided several examples from the automobile industry, he still did not focus on the automobile industry and South Korean brands. The current study involved ideas from Garvin's analysis, but focused on the U.S. automobile market and on South Korean automobile manufacturers only.

\section{Product Benefits}

Sharp (2012) found that product benefits become more and more important in business along with the development of the relationship between demand and supply in the market. This relationship is dynamic because the power of each side changes along with the development of the business world (Sharp, 2012). The fast developing business world not only fostered companies in earning incomes, it trained consumers to gain more benefits in their spending. Consumers became more rational and smarter (Sharp, 2012). Today, consumers are more concerned about product benefits rather than just quality.

According to Sharp (2012), companies need to identify product benefits from the customers' point of view because customers hold more power in today's market. Therefore, Sharp defined product benefit as the experiences, functions, and satisfaction that the customer receives from the spending. In addition, if companies want to increase their sales, they need to consider how much benefits they can provide to customers through a product with a reasonable price (Sharp, 2012).

Sharp (2012) further pointed out that product benefit in the consumers' perspective has three main dimensions. The first dimension is the brand value (Sharp, 2012). The brand value represents what the brand 
stands for and what the company promises to customers through its products or services (Sharp, 2012). The second dimension is the product value (Sharp, 2012). The product value mainly represents the product's qualities. In other words, the product value is the benefits customers receive for the price they pay (Sharp, 2012). The last dimension is the relationship value (Sharp, 2012). The relationship value is the perceived value of customers' experiences with the staff in the company. It contains the experiences communicating with company staff in sales, service, claim, and technical support (Sharp, 2012). Sharp (2012) stated that brand value and product value are constantly moving targets that are hard to measure and manage.

Although product benefits are an intangible concept that is hard to measure, they are needed to be transferred to statistical data for this quantitative research study. Schniederjans et al. (2011) developed a method of measuring consumers' perceived value by first investigating how much consumers paid for the products. Then they started to investigate how much benefit the consumers perceived. According to Schniederjans et al., product value equals the price the customer paid divided by the benefits he or she perceived. In addition, to investigate a series of products, researchers can take the average price divided by the average benefits of the products (Schniederjans et al., 2011).

The product value method developed by Schniederjans et al. (2011) provided the possibility for the current researchers of this study to calculate the benefits contained in each kind of product. In addition, by comparing the product values in numbers, researchers can easily find which company's product has the most benefits compared to its competitors. The method developed by Schniederjans et al. is not only valuable for researchers, it provides a reliable tool for marketing and industries. Companies can use this method to measure their own position and situation in the market and industries. The more comparisons are established, the more innovation can be created (Schniederjans et al., 2011). In addition, consumers will receive higher level products that contain more benefits as the result of competition in the free market.

The first step of Donnelly's (2011) theory is choosing targets wisely. Consumers are the primary judges of a product's benefits (Donnelly, 2011). Therefore, figuring out the target consumers of the product is important for investigating perceived consumer benefit (Donnelly, 2011). In fact, about a third of consumers pay more attention to product price than benefits (Donnelly, 2011). The remaining consumers are willing to spend more time to evaluate the benefits they perceive from the product (Donnelly, 2011). Donnelly pointed out that many companies have a misunderstanding of marketing that causes them to try to design marketing strategies to every possible customer. This wastes a lot of time and resources because a third of 
the work may not generate sales (Donnelly, 2011). Therefore, companies need to figure out their target customers. Working focus on a target group can enhance marketing efficiency (Donnelly, 2011).

The second step is strengthening confidence (Donnelly, 2011). To promote a product's benefits to customers, marketers need to have confidence with the product first (Donnelly, 2011). They should devote themselves to express the product's benefits and increase customers' perceptions. Lowering price is not the best choice, at least at the early stage of the promotion activities (Donnelly, 2011). Keeping confidence is not easy. Therefore, companies need to provide training for marketers to teach them how to enhance their confidence during the work (Donnelly, 2011). Donnelly said it is the most critical thing an entrepreneur needs.

The third step is leveraging the company's strengths and customers' experiences (Donnelly, 2011). Promoting a product's benefits is what makes the product stand out among the competition (Donnelly, 2011). Marketers need to wield the full weight of the company's strength to promote the product's benefits, which requires a lot of marketing skills and personal skills. However, the company has a responsibility to train its marketers to have the knowledge and skills to express the company's strength (Donnelly, 2011). One element of a company's strength is its reputation. The company and marketers can express this reputation through good feedback from existing consumers to develop future business. The reputation is a considerable aspect of brand value. Potential customers are more trusting of other customers' experiences than marketing promotions. Therefore, marketers should know how to use this source to develop product benefits in consumers’ minds (Donnelly, 2011).

The last step is emphasizing customer service (Donnelly, 2011). The product value contains, but is not limited to, the product itself (Donnelly, 2011). Beyond the product is the service, such as financing support, technical support, or warranties. If consumers can get a quick response, repair, or support when they need the company's services, they will feel that the company cares about them (Donnelly, 2011). It is better to develop rapport with consumers on a personal level (Donnelly, 2011). Services at this level are more preferred by customers. Combined with step three, companies can use customer testimonials to show future clients the value of their products (Donnelly, 2011).

Donnelly (2011) provided a valuable theory of increasing the benefits of products. The core of the theory was developing a company's own competitiveness with product benefits, but not lowering prices. Donnelly said that the benefit existed in the long term, but price only existed in the short term. Donnelly's paper did not discuss the automobile industry in his analysis. By using the ideas from Donnelly's theory, the current study was 
designed to fill the gap to test how U.S. consumers perceived South Korean automobiles' values.

\section{Methodology}

The focus of the survey was on South Korean automobile brands, with the use of Hyundai and Kia as samples. The questions were designed to investigate perceived consumer value of Hyundai's and Kia's products in order to gather useful information for South Korean automobile manufacturers to improve their business practices.

\section{Population}

The population involved in the current study was automobile consumers in the United States. As explained in previous sections, the current study was designed to investigate the perceived value in consumers' minds in order to provide useful information for their future consumption of automobiles, especially if they are interested in South Korean brands. For this purpose, the range of the population of automobile consumers included current consumers who already bought cars and potential consumers who had a plan to buy cars in the near future.

In this quantitative study, the stratified-random sampling method (Agresti \& Finlay, 2008) was adapted to establish the sample. Because this study was designed to include the whole United States and the exact number of automobile consumers in the whole country would be hard to determine, running a single simple-random sampling program was unrealistic due to the potential fiscal and time restraint limitations of this research. On the other hand, the stratified-random sampling method allowed the researchers to categorize members of the population into mutually exclusive and collectively exhaustive groups. Then, the researcher ran the simple-random sampling program in each group. For the purpose of the current study, the population was classified into 51 groups that included the 50 states and the District of Columbia. The desired sample size of the current study was 538 . Participant selection followed the U.S. presidential election method. The number of participants from each state and the District of Columbia was equal to the number of seats that each State holds in the U.S. Congress. The survey questionnaire was distributed through the service of SurveyMonkey. SurveyMonkey recruited contributing members from a diverse population.

\section{Data Analysis}

Microsoft Excel 365 and Statistical Package for the Social Science (SPSS, version 21.0) were used in this research, as the data analysis instruments. The researchers set the statistical significance at 5\% $(\alpha=0.05)$. The null hypotheses were rejected if the observed sample results were bigger 
than the statistical significance $(p>0.05)$. On the other hand, the null hypotheses failed to be rejected if the observed sample results were equal or smaller than the statistical significance $(p \leq 0.05)$.

\section{Hypothesis 1}

$\mathrm{H} 1_{\mathrm{a}}$ : South Korean automobiles’ price changes will have a significant impact on U.S. consumers’ perceived value.

$\mathrm{H}_{1}$ : South Korean automobiles' price changes will not have a significant impact on U.S. consumers’ perceived value.

Correlation analysis (See Table 1 ) reflected that price had a positive correlation with perceived consumer value $(r=0.117, p=0.003)$. The positive correlation indicates that the more money consumers spent on a car, the higher they perceived its value to be. This result confirmed that price changes have a significant impact on perceived consumer value. Thus, the null hypothesis was rejected.

Table 1

Correlation Analysis: Price and Perceived Consumer Value

\begin{tabular}{ccc}
\hline & \multicolumn{1}{c}{ Perceived Consumer Value } \\
\hline Price & $\mathrm{r}$ & .117 \\
& $\mathrm{p}$ & $.003^{* *}$ \\
\hline & $* *$. Correlation is significant at the 0.01 level (2-tailed).
\end{tabular}

\section{Hypothesis 2}

$\mathrm{H} 2_{\mathrm{a}}$ : South Korean automobiles' quality changes will have a significant impact on U.S. consumers' perceived value.

$\mathrm{H} 2_{0}$ : South Korean automobiles' quality changes will not have a significant impact on U.S. consumers' perceived value.

The correlation matrix (See Table 2) shows that perceived consumer value had a strong positive relationship with quality $(r=0.447, p<0.001)$. The positive relationship indicates that the higher the quality of the car, the more value consumers perceived. This result confirms that quality changes have a strong influence on perceived consumer value. Thus, the null hypothesis was rejected.

Table 2

Correlation Analysis: Quality and Perceived Consumer Value

\begin{tabular}{ccc}
\hline & $\mathrm{r}$ & Perceived Consumer Value \\
\hline Quality & $\mathrm{p}$ & .447 \\
& $* *$. & $<001^{* *}$ \\
\hline & Correlation is significant at the 0.01 level (2-tailed).
\end{tabular}

\section{Hypotheses 3, 4, and 5}

H3a: South Korean automobiles' fuel efficiency will have a significant impact on U.S. consumers' perceived value. 
$\mathrm{H}_{0}$ : South Korean automobiles' fuel efficiency will not have a significant impact on U.S. consumers' perceived value.

$\mathrm{H} 4_{\mathrm{a}}$ : South Korean automobiles’ design will have a significant impact on U.S. consumers' perceived value.

$\mathrm{H} 4_{0}$ : South Korean automobiles' design will not have a significant impact on U.S. consumers' perceived value.

H5a: South Korean automobiles' technologies will have a significant impact on U.S. consumers' perceived value.

$\mathrm{H} 5_{0}$ : South Korean automobiles' technologies will not have a significant impact on U.S. consumers' perceived value.

Fuel efficiency, design, and technologies reflected three aspects of automobiles' benefits. Hypothesis 3, 4, and 5 separately analyzed the associations between these three independent variables and the dependent variable of perceived consumer value. The correlation matrix (See Table 3) shows that fuel efficiency had a strong positive relationship with perceived consumer value $(r=0.470, p<0.001)$. Design also had a strong positive relationship with perceived consumer value $(r=0.635, p<0.001)$. Last, technologies had a strong positive relationship with perceived consumer value $(r=0.510, p<0.001)$. The positive relationships between these independent variables and consumer perceived value indicate that the more benefits the car added, the higher the value consumers perceived. These results provide comprehensive evidence that automobiles' benefits influence perceived consumer value. Thus, all the three null hypotheses were rejected.

Table 3

Correlation Analysis: Fuel Efficiency, Design, Technologies, and Perceived Consumer Value

\begin{tabular}{ccc}
\hline & & Perceived Consumer Value \\
\hline Fuel Efficiency & $\mathrm{r}$ & .470 \\
& $\mathrm{p}$ & $<.001^{* *}$ \\
Design & $\mathrm{r}$ & .635 \\
& $\mathrm{p}$ & $<.001^{* *}$ \\
\multirow{2}{*}{ Technologies } & $\mathrm{r}$ & .510 \\
& $\mathrm{p}$ & $<.001^{* *}$ \\
\hline & $* *$. Correlation is significant at the 0.01 level (2-tailed).
\end{tabular}

\section{Multiple Regression Analysis of Full Model}

Multiple regression was used to evaluate the significant effects of the five predictors of price, quality, fuel efficiency, design, and technologies on perceived consumer values. The first regression (See Table 4) was used to analyze these predictors' effects without controlled variables. The second regression analysis (See Table 5) added four relative demographic factors (i.e., gender, age, education level, and income level) as controlled variables.

Table 4 indicates that, without controlling for demographic variables, quality ( $\mathrm{b}=0.184 ; p<.001)$, fuel efficiency $(\mathrm{b}=0.196 ; p<.001)$, design ( $\mathrm{b}$ 
$=0.312 ; p<.001)$, and technologies $(\mathrm{b}=0.172 ; p<.001)$ were significant predictors in the full model. In addition, price was a marginally significant predictor of perceived consumer value ( $\mathrm{b}=0.041 ; p=0.144)$.

Table 4 Full Model Regression Equation Predicting Perceived Consumer Value

\begin{tabular}{cccc}
\hline R Square & \multicolumn{3}{c}{0.721} \\
0.517 \\
Adjusted R Square
\end{tabular}

Dependent Variable: Perceived Value

After controlling for the relative variables of gender, age, education level, and income level, the regression analysis for predicting perceived consumer value showed similar results as the findings of first regression analysis. Table 5 shows that quality ( $\mathrm{b}=0.184 ; p<.001$ ), fuel efficiency ( $\mathrm{b}$ $=0.196 ; p<.001)$, design $(\mathrm{b}=0.312 ; p<.001)$, and technologies $(\mathrm{b}=0.172$; $p<.001$ ) were still significant predictors in the full model. In addition, after controlling demographic variables, price was an approximately marginal significant predictor of perceived consumer value $(b=0.038 ; p=0.168)$.

Table 5 Full Model Regression Equation Predicting Perceived Consumer Value with Control Variables

\begin{tabular}{cccc}
\hline R Square & \multicolumn{2}{c}{0.722} & 0.517 \\
Adjusted R Square & Unstandardized Coefficients & \\
& $\mathrm{B}$ & Std. Error & Sig. \\
\cline { 2 - 3 } & .038 & .028 & .168 \\
Price & .181 & .029 & $<.001$ \\
Quality & .198 & .033 & $<.001$ \\
Fuel Efficiency & .307 & .027 & $<.001$ \\
Design & .173 & .032 & $<.001$ \\
Technology & .013 & .013 & .319 \\
Age & .031 & & .258 \\
Gender & -.001 & & .971 \\
Education & -.002 & & .946 \\
Income & & & \\
\hline
\end{tabular}

Dependent Variable: Perceived Value

The regression analysis did not reveal any significant effects of gender, age, education level, or income level for predicting perceived consumer value. Correlation analysis (See Table 6) showed that only age had a significant positive relationship with perceived consumer value. The other three factors did not have any significant correlation with the dependent variable. 
Table 6 Correlation Analysis: Gender, Age, Education Level, Income Level, and Perceived Consumer Value

\begin{tabular}{ccc}
\hline & & Perceived Consumer Value \\
\hline Gender & $\mathrm{r}$ & .029 \\
Age & $\mathrm{p}$ & .473 \\
& $\mathrm{r}$ & .082 \\
Education & $\mathrm{p}$ & $.038 *$ \\
& $\mathrm{r}$ & -.014 \\
Income & $\mathrm{p}$ & .727 \\
& $\mathrm{r}$ & .034 \\
& $\mathrm{p}$ & .390 \\
\hline
\end{tabular}

\section{Recommendations}

Based on the findings of this research, recommendations are provided for South Korean automobile manufacturers. It is clear from the results that consumers are not in favor of raising prices. The competition in the U.S. market is very high, so both companies need to continue with the same pricing strategy to retain existing customers and attract new customers. Maintaining this strategy will assist Hyundai and Kia to deliver long-term success. If one or both firms decide to raise the price of the products in relation to those of their competitors, sales will plummet.

The second recommendation to South Korean automobile manufacturers is to improve their products' quality and reliability to the highest level possible. The results of the analysis clearly reflected that consumers were not satisfied with the quality of Hyundai and Kia automobiles. Therefore, South Korean automobile manufacturers should enhance their standards of qualification in order to ensure their products are of high quality. The higher the level of standards, the more stable the quality. Consumers' satisfaction level will increase when the quality of South Korean automobiles becomes stable.

Finally, South Korean automobile manufacturers should conduct more surveys using social media. Hyundai and Kia need to be more engaged with their consumers. In today's economy, consumers have access to information. Using surveys to gain customer feedback can help drive South Korean automobile manufacturers' innovation to better match consumers' demands. The end result would be that consumer satisfaction with South Korean automobiles would increase.

\section{Conclusion}

The research question, what is the impact of South Korean automobiles' price, quality, fuel efficiency, design, and technologies on U.S. consumers' perceived value, was an untapped area of investigating perceived 
consumer value. Previous researchers either studied the perceived value of China-made products in the United States (Schniederjans et al., 2011) or South Korean automobiles in the Canadian market (Cato, 2014). Gathering information about U.S. consumers' perceived value of South Korean automobiles was imperative. This is attributed to the fact that they have experienced these brands for over 20 years.

An automobile's price, quality, and benefits may be the first three factors that consumers acknowledge during their decision-making process. In fact, these three aspects, as the core competitiveness of products, are also important for manufacturers. This study involved the use of a survey technique to identify how U.S. consumers evaluated the perceived value of South Korean automobiles. By analyzing the survey results, this study provided findings of associations between perceived value and price, quality, and benefits of South Korean automobiles. It is this researcher's hope that these findings will help consumers find more valuable cars and help South Korean automobile manufacturers to produce higher quality products.

In conclusion, results showed that quality and fuel efficiency, design, and technologies were the most significant predictors of perceived consumer value. The strong positive correlations clearly indicated that the higher the quality and the more benefits manufacturers applied to cars, the more value consumers perceived. Price can be a marginal predictor that also positively relates to perceived value. This finding demonstrated that an incremental increase in spending may provide consumers more values and also increase their satisfaction.

\section{References:}

Agresti, A., \& Finlay, B. (2008). Statistical options for the social sciences (4th ed.). Upper Saddle River, NJ: Prentice Hall.

Apelbaum, E. (1999, August 8-11). The importance of brand name and quality in the retail food industry. Paper presented at the annual meeting of the American Agricultural Economics Association, Nashville, TN. Retrieved from http://ageconsearch.umn.edu/bitstream/21497/1/sp99ap01.pdf

Auto-Sohu. (2014, March 11). 2014 年中国汽车行业客户满意度排名出炉.

Retrieved from http://auto.sohu.com/20140331/n397486446.shtml

Brungardt, A. (2013). Book review: The Automobile Industry: Its Economic and Commercial Development. Journal of Business of the University of Chicago, 1, 390-392.

Bullas, J. (2012, May 28). 6 powerful reasons why you should include images in your marketing - Infographic. Retrieved from http://www.jeffbullas.com/2012/05 
/28/6-powerful-reasons-why-you-should-include-images-in-your-marketinginfographic/

Buss, D. (2007). What do you mean by "vehicle quality"? Edmunds. Retrieved from http://www.edmunds.com/car-buying/what-do-you-mean-byvehicle-quality.html

Cato, J. (2014, August 7). What Hyundai and Kia need to do to get more respect. The Globe and Mail. Retrieved from http://www.theglobeandmail.com/globe-drive/culture/commentary/hyundaikia-have-a-rodney-dangerfield-problem/article19935282/

Coffey, F., \& Layden, J. (1996). America on wheels: The first 100 years: 1896-1996. Los Angeles, CA: General Pub. Group.

Donnelly, T. (2011). How to sell on value rather than price. Inc. Retrieved from http://www.inc.com/guides/201107/how-to-sell-on-value-rather-thanprice.html

Ewing, S. (2014, October 11). Kia's brand perception still painfully lags behind reality. Auto Blog. Retrieved form http://www.autoblog.com/2014/10/11/kia-brand-perception-lags-behindreality/

Garvin, D. (1984). What does "product quality" really mean? MIT Sloan Management Review, 26(1). Retrieved from http://sloanreview.mit.edu/article/what-does-product-quality-really-mean/ Goodson, S. (2012, May 27). Why brand building is important. Forbes. Retrieved from http://www.forbes.com/sites/marketshare/2012/05/27/whybrand-building-is-important/\#6115586d1e72

Harper, B. (2015, January 5). Hyundai sets sales record, growth slows. Montgomery Advertiser. Retrieved from http://www.montgomeryadvertiser.com/story /news/2015/01/05/hyundai-sets-sales-record-growth-slows/21296957/

Henry, J. (2013, February 27). Kia is on a roll in the U.S.: Say, 18 consecutive years of market share gains. Forbes. Retrieved from http://www.forbes.com/sites

/jimhenry/2013/02/27/kia-is-on-a-roll-in-the-u-s-say-18-consecutive-yearsof-market-share-gains/

Hyundai. (n.d.). A look back - Hyundai enters the U.S. market. Retrieved from http://www.hmmausa.com/?p=318

Kessler, A. (2015, January 6). 2014 auto sales jump in U.S., even with recalls. New York Times. Retrieved from http://www.nytimes.com/2015/01/06/business/us-auto-sales-jump-for2014.html?_r=0

Kia Media. (2014, June 13). Kia Motors America announces largest monthly sales total in company history. Retrieved from http://www.kiamedia.com/us/en/media 
/pressreleases/8989/kia-motors-america-announces-largest-monthly-salestotal-in-company-history

Mu，S. (2013). 现代起亚别跑太快 提升品质更重要. Retrieved from http://auto-morning.blog.sohu.com/277750359.html

Schniederjans, M. J., Cao, Q., Schniederjans, D., \& Ching Gu, V. (2011). Consumer perceptions of product quality revisited: Made in China. Quality Management Journal, 18(3).

Schweinsberg, C. (2014, October 9). Twenty years on, Kia finds perception changes slowly. WardsAuto. Retrieved from http://wardsauto.com/automakers/twenty-years-kia-finds-perception-changes-slowly

Sharp, L. (2012). Measure value creation with CRI for long-term success. Retrieved from http://www.managementexchange.com/hack/measure-valuecreation-cri-long-term-success

TrueCar. (2012a, January 11). TrueCar's performance scorecards grade the best manufacturers and brands for December 2011. Retrieved from http://blog.truecar.com/2012/01/11/truecar-com-grades-the-bestmanufacturers-and-brands-for-2011/

TrueCar. (2012b, December 17). TrueCar's performance scorecards grade the best manufacturers and brands for December 2012. Retrieved from http://blog.truecar.com/2012/12/17/porsche-leads-in-truecars-november2012-performance-scorecards-for-manufacturers-and-brands/

TrueCar. (2013, December 16). TrueCar's performance scorecards grade the best manufacturers and brands for December 2013. Retrieved from http://blog.truecar.com/2013/12/16/truecars-performance-scorecards-gradethe-best-manufacturers-and-brands-for-december-2013/

Wasserman, B. (2010). How to price your products. Retrieved from http://www.inc.com/guides/price-your-products.html

Watson, G. (2015). The strategic importance of sustainable quality. Journal for Quality \& Participation, 37(4).

Yang, K. (2006). The effects of consumer perceived value and subjective norm on the adoption of mobile data services: A cross-cultural comparison of American and Korean consumers (Unpublished doctoral dissertation). University of Tennessee, Knoxville, TN. 